\title{
Examining Social Exchange Theory and Social Change in the Works of George Caspar Homans - Implications for the State and Global Inequalities in the World Economic Order
}

\author{
Hyginus Obinna Ogbonna
}

\author{
Ph.D. Globalization and Development Studies (ABD), \\ Department of Sociology and Anthropology. \\ Faculty of Social Sciences, University of Benin, \\ Benin City, Nigeria
}

\section{Chidi Slessor Mbah}

\author{
Department of Sociology, \\ Abia State University, \\ Uturu, Nigeria
}

DOI: https://doi.org/10.36941/mjss-2022-0oo9

\begin{abstract}
This paper focuses on the critical investigation of 'Social Exchange theory' and 'Social Change' in the works of George Homans. The objectives are to appropriate the interpenetrations of the twin concepts, and their implications towards the amelioration of the human condition both within the state, and within the global socio-economic relations. Thus, the paper achieves its objectives by applying a qualitative-critical descriptive method of analysis on the subject matter -with a critique from Peter Blau's variant perspective for helpful extrapolations to explaining human condition within the state, and globally. The paper made some findings, draws conclusions, and recommendations. A few of these findings include 1) the propensities of breaching the norm of reciprocity in social exchange process are higher than the tendencies to maintain the norm;2) at the breach of the norm of reciprocity, there are higher risks of losses than the gains, and there are immanent implications; 3).That societal progress can also emerge via resistance to an 'apopular' status quo. The paper concluded that, there is a semblance of order when the norm of reciprocity is observed among nations, and within nations; but moments of aggression exists with immanent crisis-tendencies that are anti-development where the norm is violated. Therefore, the paper recommends: the state should be committed to its part of the social contract with the citizenry in terms of provisions of human-centered development facilities; and where the state loses the sanctity of its legitimacy and turns to a 'class-state', counter-reactions and resistance from the subaltern classes (the civil society) through protests for progressive social change or for the improvement of the human condition, should not be discouraged. Additionally, the advanced nations should recognize the socioeconomic rights of the less developed nations for a fair deal in the global economic relations.
\end{abstract}

Keywords: Theory, Norm of reciprocity, Social exchange 


\title{
1. Introduction
}

\author{
"There are moments such as when subaltern classes \\ would perceive a rupture between "what is" and \\ "what ought to be" and consequently either engage \\ in ideology critique and/or political action in a bid \\ to ameliorate ontological social conditions \\ [to bring about change]". Ninalowo (2004:47).
}

Although, the primary assumptions of the twin concepts of social exchange and social change may run parallel to each other, their interpenetrations and inter-linkages are quite germane in giving explanations to the socio-political currents of the desideratum for the amelioration of the human condition. It was due to their interconnectedness in explaining the human condition that prompted Ninalowo (2004) to rightly affirm that, what is quite often forgotten in moments of domination [hegemonic unequal exchange relationship] is that there is a logical interrelatedness between domination [unequal exchange relationship] and resistance (a moment of social change). We shall return to demonstrate this in the furtherance of this endeavor.

To be sure, social exchange theory of George Caspar Homans hinges on the 'norm of reciprocity' which shares an epistemic nexus with Bentham's Utilitarian Economics. Utilitarian economics suggests that economic behavior should be predicated on a "Quid pro Quo" relational basis -that is, "something for something". In all intents and purposes, Homans' frame of reference suggests that, in the course of social intercourse, we expect enjoyment of mutual advantages. It is due to this affinity that Homans' persuasion of social exchange shares with utilitarian economics that prompted the description of Homans' postulation as, 'The Return of the Ghost of Utilitarianism' (Muldoon, et al 2018: 57-75). Although, Homans' conjecture is anchored on the behavioral assumption of mutual advantages, he has, however, conspicuously ignored the dynamics of crisis-tendencies and ruptures, 'selfishness and limited generosity (Levin, 2021), and domination-resistance propensities replete, overtly or covertly, in social exchange relationship; to which Peter Blau (Cook, et al 2013) in his own nuanced frame of reference filled the epistemic gap with a slight touch of epistemological break from Homans', by demonstrating the existence of unequal power relations in social exchange process.

With regard to the notion of social change, the paradigm is relevant to understand current affairs as regards the status quo of things in the social contract between the state and the citizenry. To be sure, positive changes (i.e. progressive type) can be brought about by the state in terms of provisions of human-centered development facilities; however, social change is equally possible to be invoked by the actions of the aggrieved party in a social exchange process -typically, in the attendant immanent contradictions within the matrix of the contractual social exchange relationship between the state and the citizenry. We shall return to this shortly.

Thus, in the light of the forgoing utterances, and for a proper articulation of the discourse, this paper is structured along the following rubrics: first, brief biography of Homans; An overview of Homans' notion of Social Exchange; Evaluation of Homans' conjecture from the point of view of Peter Blau's variant perspective; Social change -An overview; The interpenetrations of the twin concepts of Social Exchange and Social Change with relations to the human condition -Implications for global inequalities in the world economic order. Then, findings, conclusions, and recommendations come on course. It is hoped, and desirable, that these thematic outlines shall help in giving this treatise the desired scholarship.

\section{Statement of the Research Problem}

Social inequalities pervade almost all structural forms of human relations, essentially exchange relations: from dyad or two persons exchange relations, to macro global levels of exchange relations. And these inequalities, whether at micro level of individuals' relation or macro levels of the state 
versus the citizenry, and/or global dimensions of the state versus other states in the global economic relations, portend some immanent contradictions of power domination and its manifest consequences that are inimical to human condition and the maintenance of social order within the state, and outside the state's frontiers among other state actors in the global economic relations; having consequences that manifest themselves in forms of violence, ethnic-minority crises, civil protests, terrorists attacks, anti-state/secessionists' agitations, and other forms of political instabilities and insecurities to lives and properties that threaten egalitarian, peaceful co-existence. Thus, with the pervading intensity of these manifest social implications or antinomies of inequalities that exists in social exchange relations both within and outside the state's frontiers in recent times in global history, it becomes imperative to enquire: in what ways can the Social Exchange theory of George Homans, and the notion of Social Change in development discourse proffer helpful insights to mitigating these inequalities and their antinomies that are endemic in social relations? In what ways can insights drawn from the twin concepts of Social Exchange theory and Social Change help in promoting a progressive change for societal development? Thus, how the results or findings of these enquiries will help in mitigating the pervading antinomies that exist in exchange relations geared towards a progressive societal development remains the focus of this investigation.

\section{Objectives of the Study}

The general objective of this paper is to explore, critically, the notions of Social Exchange theory and Social Change in the works of George C. Homans; however, the specific objectives include: i). to examine what implications such notions hold for the state and global inequalities in the world economic order, ii) to appropriate these implications with the view to improving the human condition in modern society.

\section{Research Methods}

\subsection{Qualitative Method}

The paper adopts qualitative descriptive method of analysis. This entails a descriptive presentation of ideas or insights gleaned from relevant literatures, and author's observations of events in society.

\subsection{Expected Results}

It is expected that the paper should uncover some findings which shall help in proffering policybased recommendations that are constructive towards mitigating the immanent contradictions fraught with social exchange relations at all levels of social interaction for a progressive societal change in view of ameliorating the human condition.

\subsection{Conceptual Clarifications}

There are certain peculiar concepts or terminologies employed in the epistemic lexicon of this discourse that need to be de-mystified for clarity purposes. These include as follow:

\subsection{Theory}

A theory is an analytical framework or paradigm used to study and interpret social phenomena (Seidman, 2016). Similarly, it is an explanatory framework that seeks to explain a natural phenomenon. According to Abend (2008: 173-199), "a theory is an explanation of a particular social phenomenon...an overall perspective from which one sees and interprets the world". Thus, for the sake of the discourse; in contextualizing the meaning of "theory" to 'Social Exchange', it therefore 
connotes a system of related ideas or explanatory framework that seeks to explain, interpret or predict social exchange behavioral processes.

\subsection{Norm of Reciprocity}

Norm, here, refers to "principles" or "rules guiding behavior". Hence, 'Norm of Reciprocity' can be interchanged with 'Principles of Reciprocity' or 'Rules of Reciprocity'. Reciprocity, on the other hand, literarily means, 'Give and take'. However, for our purpose here, 'Norm of Reciprocity' shall be defined as, the grand norm that governs socio-economic behavior of give and take -that is, "quid pro quo" (something for something). That is to say, the 'Norm of Reciprocity' presupposes that in the course of social intercourse, we expect enjoyment of mutual advantages. For the sake of in-depth understanding, Cyberclass.net posits the following specifications: i). Giving and taking something mutually; ii). Making a return for something done or given; iii). Being complementary or at least equivalent. Thus, at the risk of over simplification, the 'Norm of Reciprocity' is reducible to the assumption of the cliché or the worn-out expression, "you scratch my back, and I scratch yours"!

\subsection{Social Exchange Theory}

Initially, social exchange theory, in situ, was the province of behavioral psychology which seeks to explain the patterns of cause and effects of actions and rewards involved in a dyadic (two-person) process of social intercourse. However, Homans gave it a utilitarian economics orientation that hinges on norms of reciprocity. Hence, for our purpose here, social exchange theory shall be defined as, an explanatory framework which anchors its explanations of the behavioral patterns of parties engaged in social intercourse on norms of reciprocity (quid pro quo: something for something). That is, in the course of social interaction, we expect enjoyment of mutual advantages: if our expectations are fulfilled in respect to norm of reciprocity, we enjoy satisfaction; if otherwise, we are likely to express aggression. We shall revisit this in details in the course of the discourse.

\section{Literature Review}

\subsection{Historical background (biography) of george c. Homans.}

George Caspar Homans was born in Boston, Massachusetts August 11, 1910. Homans entered Harvard College in 1928 with an area of concentration in English and American Literature (Feraro, 2015). In 1932, Homans bagged his bachelor's degree from Harvard (Ritzer, 2007). In fall of 1932, L.J. Henderson, a physiologist, was offering a course in the theories of Vilfredo Pareto, and Homans was invited. His exposure to Pareto led to a book, 'An Introduction to Pareto' (co-authored with Charles Curtis), published in 1934 (Ritzer, 2007). The publication of this book made Homans a Sociologist even though Pareto's work was virtually the only sociology he has read up to the point.

In 1934, Homans was named a junior fellow at Harvard in the newly formed society of fellows at the College, while at the same time undertaking a variety of studies in various areas, including sociology, psychology and history. In 1939, he became a Harvard faculty member, a life-long affiliation in which he taught both sociology and medieval history. By virtue of his later theoretical writings, he became a major theorist, and in 1964 was elected President of the American Sociological Association. Some of those his theoretical writings include, 'Theoretical Agenda', 'The First Phase', 'Second Phase', and 'The General Argument'. Within Sociology and Social Psychology, Homans was regarded as one of the major Sociological theorists in the period from the 1950s to the 1970s. He was equally the American founder of behavioral Sociology and the Exchange theory. However, in May 29, 1989, Homans died in Cambridge Massachusetts. Some of his books include, 'English Villagers of the Thirteenth Century (1941), 'The Human Group (1950), Social Behavior as Exchange (1958), Social Behavior: Its Elementary Forms (1961, 1974). 
Having attempted the biography of Homans, we shall now return to the main task of this endeavor as was promised ab initio. First, we shall have an overview of Homans' notion of Social Exchange.

\subsection{Homans' conjecture on social exchange -an overview}

Social behavior is an exchange of activity, tangible or intangible, and more or less rewarding or costly between, at least, two persons. (Redmond, 2015; quoting Homans)

The kernel of Homans' theoretical presentation is the 'norm of reciprocity'. Homans' exchange theory is predicated on behavioral assumption in conjunction with hedonistic assumptions from utilitarian economics of Bentham (1748-1832). These assumptions are anchored on norms of reciprocity in terms of ensuring a semblance of order between the parties in the exchange relationship. Utilitarian Economics suggests that economic behavior should be predicated on 'quid pro quo' basis -that is, something for something. The norm of reciprocity proposes that in the course of social intercourse, we expect enjoyment of mutual advantages. If our expectations are fulfilled in respect of the norm we enjoy satisfaction, and contrariwise we are likely to express aggression. In his 'Social Behaviour: Its Elementary Forms (1961, 1974)', Homans acknowledged the fact that his exchange theory is a derivative of both behavioral psychology and elementary economics of utilitarianism to which Talcott Parsons (1960) acknowledging instructively, attested to the veracity of Homans' admission, thus describing Homans' conjecture on Social Exchange as the resurgence of utilitarian economics - in own verbiage, Parsons called it "The Return of the Ghost of Utilitarianism" (Muldoon, et al 2018: 57-75).

To be sure, Homans' theory envisages social behavior as an exchange of activity, tangible or intangible, and more or less rewarding or costly, between at least two persons. Thus, Homans' theory originally focused on the psychological level of dyadic social interaction between two persons. Perhaps, this conclusion is justifiable because, according to Homans, no new propositions are needed to explain social behavior as opposed to individual behavior. For the sake of elaboration and a deeper insight, we shall like to introduce at this point the set of fundamental propositions, which, according to Homans, are the basis for his exchange theory of social behaviour. They are adumbrated in sequence, as follow:

\subsection{The Value Proposition}

The crux of the value proposition is, the more valuable the consequence of one's action is, the more likely one is to perform the action another time. That is, if the reward each of the parties in the social exchange relations receives for his action is valuable, then the more likely both parties are to participate in the same action in the future.

\subsection{The Aggression-Approval Proposition}

It has two dimensions: Proposition A) states that when a person's action does not receive the reward he expected, or receives punishment he did not expect, he will be angry. That is, the unsatisfied party is more likely to choose aggressive action in future since his previous good action was not rewarded as he expected. Proposition B) states that when a person's action receives the reward he expected or more than he expected, or does not receive the punishment he expected, he will be pleased. That is, a satisfied party is more likely to engage in that approved action in the future since the previous action was rewarded or approved. 


\subsection{The Success Proposition}

It states that, for all actions taken by persons, the more often a particular action is rewarded, the more likely that particular action will be repeated by the person. That is, parties in exchange relations are more likely to repeat any action that was rewarded in the past, and least likely to repeat any action that was not rewarded.

\subsection{The Stimulus Proposition}

This states that, if at the occurrence of a particular stimulus, the actions of two individuals were rewarded in the past, the two individuals are more likely to engage in similar actions if similar stimulus occurs in the future. For instance, if two people in a social interaction feel happier whenever they go to the garden for their interaction than any other place, the more likely they are to use the garden for their interaction in the future than any other place.

\subsection{The Rationality Proposition}

This states that, in choosing between alternative actions, a person is more likely to choose the one that has the highest value $(\mathrm{V})$ or the one that has the highest probability $(\mathrm{P})$ of getting the expected result. In this case, the 'value' and the likelihood/'probability' of getting it are very imperative.

Therefore, Homans' social exchange theory can be condensed to the conclusion that, actors involved in the social exchange process are rational profit seekers; that is, seekers of 'mutual advantages' that underline norms of reciprocity (quid pro quo).

\subsection{Evaluating Homans' Conjecture From The Critical Perspective Of Peter Blau}

In his nuanced perspective on Social Exchange, Blau was interested in social exchange relations as it affects the distribution of power in society (Scott and Craig, 2004). To Blau, where there is unequal social status among social actors or participants in social exchange relations, the exchange process does not thrive favorably as it does not allow equal potential for mutual advantages or mutual benefits. Thus, in terms of the 'norm of reciprocity' (something for something) which is the grand norm of social exchange theory according to Homans' tradition, Blau was of the opinion that, it is not all the time that two parties in exchange relations would have equal benefits or equal rewards (i.e. the 'equilibration' notion of Homans) to share. Sometimes, one party may have something to offer more than the other party: as a result, there will develop power relations in the exchange process where the one with a higher benefit or higher value offer will wield power over the other party with less rewards or value. This engenders imbalance or unequal exchange relations with immanent contradictions of conflicts that may ensue in such imbalance. Hence, Blau was of the opinion that, while social exchange relations can engender bonds of friendship [in terms of mutual advantages or equal value offerings] it can as well establish super-ordination over others (Redmond, 2015). That is, in any exchange relations where one party is the only one supplying the needed reward, the individual exercises power over the other party that brings less. This is typical of the global relations between the advanced Global North countries and the poor Global South in the world economic order. The advanced nations are always the one playing the "big brother role" over the Third World nations, always the ones forgiving the debts of the developing nations, always the ones giving development aids to the poor nations; hence, this has always subjugated the poor nations of the Global South under the economic power and hegemonic influence of the advanced nations. Thus, to Blau, power results from unequal exchange, stemming from individuals' or groups' monopoly over desired resources (Redmond, 2015). Blau's frame of reference is reducible to the following principles:-

Principle 1: The more services supplied in return for receipt of some valued services, the more power held by those providing the valued services. 
Principle 2: The more alternative sources for reward possessed, the less those providing the reward can extract compliance. That is, if party B can get the same resources for which party A has subjected party B into dependency and subservience from another source, the less likely party A can exert power over party B or extract compliance from party B in their exchange relations.

Principle 3: The more those at the receiving end can apply force and coercion, the less those providing the reward can extract compliance. This is in line with Marxian conflict perspective of the revolution of the proletariat, the subordinate class. That is, the more those at the dependency class (dependent individuals or nations) through aggression or revolution break out of the chain of dependency from the hegemonic influence and subjugation of the more powerful advanced nations, the less the poor dependent nations will be exploited or coerced into subjugation. This line of thought, historically, has led to the political independence of many nations of the world - including America that gained independence in July $4^{\text {th }} 1776$ from the Great Britain after America revolted against Britain in the historic 'American Revolutionary war of 1775 to 1783 ' -from their former colonial master (Britain).

Principle 4: The more receivers can do without the reward, the less the providers can extract compliance. If poor nations can integrate internally and grow their domestic economy, engage in intensive development of their human and material resources, pursue import substitution industrialization policies (Hunt, 2016) where they could produce locally made goods that are close substitutes to the ones imported from the advanced economies, pursue 'trade protectionism'; that is, protect their infant industries from the harsh and unfavorable competition of the international market (Chang, 2002) by developing and strengthening their domestic industries first, develop a selfsustaining economy and depend less on the advanced nations, the less the advanced nations can subjugate them into dependency positions. Supporting this, the Structuralist, Raul Presbisch, was of the opinion that, economic inequalities and distorted development experienced by developing nations is an inherent structural feature of the global system exchange or trade (Hunt, 2016). In the historic 'East Asian Miracle', it is believed that the East Asians adopted import substitution strategy in growing their domestic economies. The East Asian Economies concentrated on strengthening their domestic economic pillars (human capital and infrastructure) -they engaged in high savings rate culture, made enormous investment in human capital, educating large numbers of skilled engineers able to absorb and adapt the most advanced technology (Page, 2016) and promoted indigenous industrial firms. Japan, one of the eight East Asian nations (Japan, Indonesia, Taiwan(China), Singapore, the Republic of South Korea, Thailand, Hong Kong, and Malaysia) that pulled the miracle, through self-imposed peaceful isolation for two and half centuries (prior to 1853), and during the Meiji enlightenment era (1868-1912) thrived on import substitution economic strategy: for economic and political security, Japan shunned the economies of the advanced nations and concentrated on building their domestic productive base for several years to catch up with the Western Powers before opening up to the economies of the advanced nations (World Bank, 2001; Gordon, 2003 and Mossi, et al. 2015).

The kernel of Blau's variant frame of reference on Social Exchange process is that, the social actor who has the valued resources or reward is usually the one with the power. Hence, there is usually a skewed or unequal unsatisfactory relation between the social actors in such unequal exchange process. It equally holds immanent contradictions of conflicts and/or aggression emanating from the skewed exchange relation as the subjugated party will tend to revolt to break out of the exploitative and hegemonic exchange process -This gives credence to many terrorists' attacks from some irate and disgruntled Third World nations against U.S.A who has played the 'Big Brother Role' over many developing nations for a long time. Clearly then, Homans' notion of social exchange is devoid of power and authority which is preponderant in unequal social exchange situations as exemplified with Blau's variant perspective. That is, Homans was oblivious of the fact that in an exchange relation, one party tends to become more powerful than the other, and hence possibilities of 'domination-subordination' that is fraught with resistance or opposition is usually not lacking in such situations. In Homans' theoretic departure, there is the assumption that parties in social 
exchange process enjoy equal powers. That is, he dwelt more on the assumption that the two parties will have mutual advantages, and their interactions be carried out on equity lines of 'something for something' (quid pro quo). But that rather exists in ideal situation than praxis situation. Thus, it is at this epistemic departure that Peter Blau's paradigm attains an epistemological break from Homans persuasion. In concrete terms, it is this 'differentia specifica' between Homans and Blau that influenced Blau's variant of social exchange theory. While Homans was interested with social exchange process at the micro level of individuals dyadic process, Blau was more interested with interaction situation among large-scale structures that explain complex social behavior beyond the individual level of dyadic process that were of great concern to many Sociologists. A typical extrapolation of this structural power imbalance from the theoretic lens of Blau's exchange theory which typifies the equation of the 'domination-subjugation' relations among countries (especially, between the advanced and developing nations) in the global economic order, with its immanent contradictions, shall be demonstrated in the furtherance of the discourse.

\section{Social Change - An Overview}

Social Change is the significant alteration of social structure and cultural patterns through time (Leicht, 2018). Culture here refers to the way individuals or groups do their things -shared ways of living among people. From Leicht's (2018) definition, properly conceived, social change refers to any significant alteration over time in behavioral patterns and cultural values and norms. Sociologists in their professional 'sociologese' or sociological lexicon or jargon usually refer "significant alteration" to mean alterations or changes precipitating profound social consequences or social outcomes. Although, historically, significant changes that could bring about long-term social change was usually attached to the dynamics of industrial revolution, urbanization or abolition of slave trade, etc.; in recent times, however, social factors that could inspire or trigger actions of disgruntled or discontented members of society to bring about social change have become of interest to many sociologists -like the social change that could emerge as a result of the immanent contradictions of power relations in a skewed or unequal social exchange process among individuals or groups; where the subordinate, unsatisfied party in the exchange process can revolt against the status quo which could precipitate change (a la Blau, 1964). Sociologists use two theoretic paradigms to explain this (i) Relative Deprivation, and (ii) Resource Mobilization.

Relative deprivation, states that when members of a social group become dissatisfied, frustrated or discontented with the economic, political or social situation they found themselves, they agitate or yearn for change. Thus, a relatively deprived group is discontented or disgruntled because they feel less entitled or less privileged than the other reference group that appear to enjoy these collective group resources or reward than they. Resource mobilization paradigm, on the other hand, focuses on how effectively and efficiently the disgruntled social group or class can mobilize resources and organize themselves to fight for change. Organized social movements like civil societies headed by a charismatic leader and with mobilized resources can bring about change in the vexing status quo that is the object of contestation.

According to Ninalowo (2004: 129), "the concept of social change embraces historical moments that are dynamic whose patterns may be either progressive or retrogressive, or mixed". Progressive, because certain societal alterations of its structural or institutional patterns may be functional to bring about positive changes for societal progress or growth; and retrogressive, because some changes can equally be dysfunctional to societal progress or growth, and sometimes there may be an admixture of the two polar socio-structural change and their consequences. With regard to the progressive type of change, properly conceived, as Ninalowo (2004: 130) instructively intimated, "the inherent properties of progressive social change implies that it is tantamount to human-oriented development". However, it is not only normative actions that can bring about progressive change, say, the human-oriented development. Sometimes, actions that deviate from the norm or from the rules of the game, like actions of the subaltern class -an aggrieved and discontented party in a social 
exchange relations with a dominant class -may through their 'counter-hegemonic' response of resistance to the domination of the powerful class bring about a progressive social change in dismantling the vested, selfish interest of the dominant class and create a new status quo that embraces social justice and social inclusion of the excluded. This can occur, by way of popular protests, demonstrations or strike actions of the subaltern class against the structural power imbalance and its anti-human consequences to the human condition. The crux of the deliberations here is that almost in all situations where domination exists; that is, where power is exercised over others, are usually potentially and immanently conflictual. And such conflicts can bring about change, even the progressive type of change!

6.1 The interpenetrations of the twin concepts of social exchange and social change -with regard to the human condition in the state and global relations

Perhaps, a useful starting point under this rubric is to address the issue at hand at two epistemic levels: first, a). at the level of the relationship between the 'state' and the 'citizenry'; and second, b) at the level of the asymmetrical global relationship between the 'developed' and the 'developing economies'. We shall address these thematic outlines, et seriatim in what follows:

At the level of the relationship between the state and the citizenry

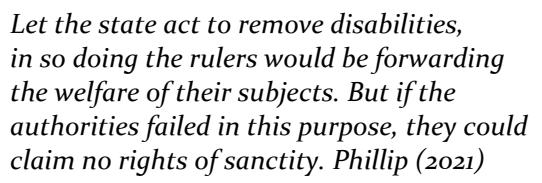

Although, Homan's theory of social exchange primarily examines a dyadic social intercourse between two individuals, its import -especially when interlaced with, and viewed from the theoretic lens of Blau's variant -allows for extrapolations and reconstructions with a view of investigating how exchange relationship among complex groups like the 'state' and the 'citizenry' is possible in terms of their perceived mutual advantages and their immanent antinomies or contradictions. Two germane concepts in the understanding of the matrix of the relationship between the state and the citizenry with the interpenetrations of social exchange and social change theoretic undercurrents and their extrapolations -shall be proposed here: this can be captured via the mediation of the concepts of 'Social Contract' and 'Legitimation-crisis'.

The bit about 'social contract' is that, there is an "ideal" agreement between the state and the citizenry where the state is charged with the responsibility to provide human centered development facilities or socioeconomic empowerment services and structures for the citizenry; while the citizenry in turn, on the other side of the contract, is charged with the responsibility to perform their civic duties (payment of taxes; law abiding) to the state. In fact, this sacred contractual expectations between the two parties to the contract (the state versus the citizenry) is best captured in Ninalowo's (2004) instructive utterances, "according to this doctrine (social contract), in return for taxation, it was the duty of the state to provide the enabling environment and opportunities for basic needs pertaining to jobs, health care, housing, etc." (p.7). From the antecedent and the ontological existence of the notion of social contract, the ideological intent of the earliest political philosophers who theorized on the notion of social contract especially Hobbes (1588-1679) and John Locke (16321704) was that, while the people have surrendered their political will or rights to the body-politic (the state) to rule over them, the state should manage the affairs of the society on behalf of all. Idealtypically, the power of the state, "must be exercised, as it is given, for the good of the subjects" (Appadorai, 2003: 25). And the subjects, here, being the citizenry who entrusted the state with the political power to rule!

Similarly, the raison d'etre of the state qua state is anchored on actual manifestations of its 
socio-political legitimation -that is, 'legitimation as praxis! Legitimation means the process by which the body-politic (the state) seeks to gain the allegiance and loyalty of its citizenry, and in the process to make the people adhere to the dominant value system and norms (Ninalowo, 2004). That is, the power the state wields (here, the political class or the rulers) is considered to be legitimate if the political class has the popular support; put differently, the state is legitimate where the right of the political class to rule over the people is accepted and recognized by the people (who hold the popular sovereignty). Therefore, for the state to endure it must always crave for the popular support; and the means of gaining this popular support or allegiance of the citizenry is usually through the provisions of the socioeconomic empowerment facilities for the people by the state as adumbrated in the forgoing utterances. As corroboration to this position, Ninalowo (2004:37) writing with great intellectual audacity affirmed that, "the ultimate dynamics of legitimation goes beyond sheer legalization of elitist national goals. The ultimate test of legitimation resides in people's fulfillment of their needs, aspirations, values and interest. That is, socio-political legitimacy". That is, what makes the state legitimate is not the existence of these provisions in legal codes or in mere legal semantics but the actual performance -that is legitimation as praxis!

By the same token, whereas the state can only be legitimate with the provisions of these human development services; its failure to provide these services and ameliorate the socioeconomic conditions of its citizenry and rather metamorphoses into a 'class-state' (i.e., a ruling class for its own vested class interest instead of its raison d'etre for the general interest of the people) is tantamount to legitimation-crisis. Legitimation-crisis refers to ruptures or distortions between 'what is' (reality) and what 'ought to be' (ideal). This crisis reproduces itself in forms of counter-hegemonic protest activities of the subaltern classes (the civil society: trade union, irate youths, peasants, urban professionals, etc.) which further, in a systemic consequences, causes ripples of political instability in monumental proportions; and which by nature, in itself is anti-development! A clear case of such moments of legitimation-crisis caused by the state irresponsibility to its contract with the citizenry and the counter-resistance from the citizenry is the '2020-End SARS' national protests by the irate youths of Nigeria, during the administration of President Buhari, who took to the streets in all states of the federation in October, 2020 for two weeks clamoring against police brutality and unresponsiveness of the Nigerian government to the worsening socioeconomic conditions of the Nigerian people. The protests reached epic proportions as the irate youths refused to leave the streets in all states only to be dislodged by repressive measures of the Nigerian government who sent soldiers who shot some of the armless protesters especially at Lekki Toll gate Lagos where some of the protesters camped in their agitation. There were anti-state counter-responses as many public properties including many police stations (some police personnel lost their lives as well) and other public infrastructures were destroyed in counter response to the killing of many youths that were shot by the soldiers. Thus, such instability reproduced anti-development consequences or negative outcomes in a nation's development process; that, in itself, is social change in Nigeria's social structure, but a retrogressive type of change!

Now, with the forgoing conceptual expositions on the twin concepts of social contract and legitimation-crisis, it becomes easier, at this point, to appreciate the interpenetrations of social exchange theory and social change and their extrapolations with regard to the relationship between the state and the citizenry in the amelioration of human condition.

\subsection{Extrapolations from Social Change, Social Contract and Legitimation-crisis}

"Political problems come from the fact that we are all subjects and yet we look upon other people and treat them as objects". Marleau-Ponty (Ninalowo, 2004:37, 98).

In the light of the preceding, further extrapolations and reconstructions can be distilled within the matrix of the state and the citizenry which shall be very constructive to aid more insightful and a 
better appreciation of the discourse.

Beginning with Social change, the concept implies alteration in the structure or organization of society or its component parts over time. As was hinted ab initio, the concept of social change embraces historical moments that are dynamic whose patterns may be either progressive or retrogressive or mixed. Progressive social change is evident where the state aligns its policies toward making provisions for the availability of human-centered development facilities (housing, jobs, good roads, and health care, et cetera) to bring about positive or progressive development. It is worthy of note here that the resistant activities of the subaltern class (the civil society: organized protest groups or irate citizens) can equally bring about positive or progressive change. Retrogressive change, on the other hand, entails limited welfare opportunities for the interest of the masses; while "mixed" type of change is an admixture of both progressive and retrogressive change -that is, such change may be partly in a desired direction and partly in an undesired [dysfunctional] direction.

Meanwhile, our aim here is to demonstrate the interpenetrations of the twin concepts of social change and social exchange with insightful extrapolations in giving explanations to certain crisis tendencies and immanent contradictions existing in the contractual exchange relationship between the body-politic (the state) and the citizenry in view of the amelioration of the human condition. Putting into focus our earlier proposed mediating concepts of social contract and legitimationcrisis as expounded above, the state is in a matrix of contractual exchange relationship with the citizenry to provide welfare facilities to improve socioeconomic status of the people; while the citizenry in turn pays taxes to the state (for the social services gained from the state): this presupposes an equal power relations between the two parties (the state versus the citizenry) along the epistemic theoretic principles of Homans' exchange relations. However, that exists only in utopian situation. In reality, while the citizenry pays their taxes to the state, the state (the ruling class) utilizes the public funds for its own vested class interest ('class-state' interest) rather than for the generality of the entire citizenry -the "lootomania" culture among our political leaders; overinvoicing; inordinate privatization of public properties which usually enter back, secretly, into the selfish hands of the same political leaders that privatized them, where only their wards and cronies are favored to get jobs in these corporations while the remaining qualified citizens wallow in unemployment and under-employment, are cases in point: glaring evidences of these claims can vividly be captured. In the first place, the corrupt and very laughable (yet very pathetic) financial grafts incidence in Nigeria during the first tenure of President Buhari as a civilian president (20152019) where 'snakes' (a reptile specie) and monkeys were purported by the political class to swallow money. For instance, it was alleged that snakes swallowed N37 million at JAMB office vault (Vanguard February $17^{\text {th }}$. 2018), while another older specie of the animal kingdom, the monkeys swallowed N70 million belonging to the Northern Senators Forum (NSF) under the watch of Senator Adamu (who was then being dismissed as the NSF chairman) who claimed that the missing $\mathrm{N}_{70}$ million was swallowed by monkeys in his farm (Vanguard February 21, 2018); this was amidst the rising incidence of poverty in the nation, especially in the Northern part of Nigeria as the World Bank (2020) reported that $87 \%$ of poor people in Nigeria are from the North. And more than 82 million Nigerians live below the poverty line of less than $\$ 1$ per day (NBS, 2020), with urban poverty index rated at $18.04 \%$ and rural poverty index estimated at $52.10 \%$ (NBS, 2020). Additionally, during the administration of former military President, Major General Ibrahim Badamosi Babangida (retrd) in 1991, Nigeria earned a huge sum of money to the tune of $\$ 12.4$ billion USD (Daily Independent July 31, 2010) in oil exports during the Gulf war (Iraq-Kuwait war) of 1991 in what was tagged to be an "oil-wind fall" that brought the international oil price to unprecedented levels; and yet such revenue never reflected on the welfare of the Nigerian citizens as the human development index for Nigeria in 1990/1991 was abysmally low at 0.242 (UNDP, 1991) ranking 129 out of 160 countries reviewed in 1991 (UNDP, 1991). Poverty level at the same year was $42.7 \%$ (NBS, 2003) increasing to $65.6 \%$ by 1996 (NBS, 2003) 5 years after the "oil-wind fall" -signifying that the oil gains from the 1991 "oil-wind fall" never reflected on the wellbeing of Nigerians. Therefore, the above contextual instances of the corrupt practices of the vested interests of the 'class-state' (the selfish political class) in the contractual relationship between 
the state and the citizenry suggests a breach or distortion in the ethos of reciprocity that ought to have existed in such exchange relationship; hence, the grand 'norm of reciprocity' is abysmally reduced to "quid pro non" (something for nothing) instead of "quid pro quo" (something for something) according to Homans' social exchange doctrine. Thus, the failure of the state in fulfilling its part of the bargain in the exchange relationship with the citizenry is reducible to legitimationcrisis, which is capable of kicking up oppositions from the aggrieved and unsatisfied party to the social contract (the citizenry) in forms of revolutions and counter-hegemonic activities of the subaltern classes (protest groups, trade union, urban workers, and irate youths etc.) whose resistant actions may result into progressive social change to alter the structural status quo geared towards provision of those human-centered development facilities which the dominant party to the social contract (the state) failed to provide.

Ideal-typically, the forgoing thought process provides understanding for the existing crisistendencies and ruptures in Nigerian social structure nowadays, which evidently has manifested itself in the revolutions and separatists agitations of the Niger-Delta Militants, and other disgruntled groups like the Indigenous People of Biafra (IPOB) seeking to "exit from the state", who are aggrieved because the state (the ruling 'class-state') has failed to fulfill its part of the bargain in the contractual exchange relationship as regards ameliorating their socioeconomic conditions. Therefore, the moments of 'domination-resistance' emanating from the unequal power relations in the contractual exchange relationship between the state and the citizenry, is inter-linked with social change! Although, to a limited or greater extent, such resistance can be minimal or none (hence, limited social change in terms of resistance-induced change) where the social exchange relations existing between the two parties is "lived" along the lines of social justice with strict observance of the "quid pro quo" grand norm. But such situation of equity may be practically impossible due to the "selfishness and limited generosity" (Hume, 1948) of human species. That is, if the relationship between the state and the citizenry conforms to the norm of reciprocity, there will be a semblance of order (homeostasis); hence, limited resistance-induced change; contrariwise, tendencies of mutual aggression will ensue!

However, this investigation shall be incomplete if we neglect to explore further at the level of global relations among developed and developing nations. To this we now turn.

\subsection{At the level of the unequal global relations between advanced countries and the peripheral economies}

In concrete terms, the relationship existing between the developed societies and the developing societies (i.e., the Global South countries), ideal-typically, exists along social exchange lines. Conventionally, such exchange relationship ought to exist along egalitarian lines (speaking from Homans' theoretic perception) where there ought to exist equal power relationship between the developed countries and the peripheral societies, at least with the sole utilitarian intention of "something for something" (quid pro quo basis) in consistency with the conceptualized notion of social exchange, a la Homans. For instance, the relationship existing between the high oil consuming developed nations of the world (like, U.S.A, Britain) and the oil-exporting less developed nations (e.g., Nigeria) shares a social exchange nexus which ought to exist on egalitarian power relationship of 'quid pro quo'. That is to say, each of the parties having something of value to offer without subjugating the rights of the other. To be sure, in such a relationship, Nigeria (the oil-exporting party) having something of value (her oil) ought to get something of value in return (like, gains of foreign exchange that does not accrue from pre-determined and controlled prices by the advanced nations at the international market: typical of this anomaly is the European Brent crude oil price, and sometimes the West Texas Intermediate (WTI) crude oil price of U.S.A, by which less developed oil exporting nations fix their oil prices as a benchmark; or have a rub-off of advanced nation's improved technology on the local economies as a positive outcome of their contact with the advanced nations in the exchange relations) without having to be dominated economically by the other party (the 
advanced nations). The advanced nations in their exploitative tendencies through their Multinational Corporations (MNC's) have their parasitic roots or tentacles almost across all countries of the developing world, exploiting their natural resources while leaving these underdeveloped nations poorer than the way they met them.

Paradoxically, therefore, Homans' theoretic paradigm does not apply in praxis situation. There have been evidences of 'domination-subordination' matrix existing in the social exchange relationship in the global economic relations between the developed and the developing nations. The relationship is never that of 'quid pro quo' (something for something) but rather, 'quid pro non' (something for nothing) - which underscores the reason for the unbridled, unequal economic relations, and the continued underdevelopment of the peripheral economies despite their protracted economic contact with the advanced nations. This standpoint can be demonstrated by the dependency notion of 'development of underdevelopment' (Cristobel, 2018). That is, properly conceived, the relationship favors the development of the advanced nations, while reproducing the underdevelopment and/or pauperization of the poor nations -thus, revealing an unequal economic power relation that is rather consistent with the conceptualized social exchange variant of Peter Blau's than Homan's.

This unequal economic power relation is fraught with immanent contradictions: it is capable of reproducing oppositions and grievances of the aggrieved party (the exploited Third world nations) in forms of counter-hegemonic activities of subaltern individuals -terrorists' attacks, political rebels who engage in revolutionary movements that may usher in social change. Thus, the 'dominationsubordination' existing in the politico-economic currents of the global economic relations provides explanations for Iraq's and North Korea's opposition to U.S hegemony; and the terrorists oppositions of some subaltern individuals like the Al-Qaeda network spearheaded by the notorious late Osama Bin Laden. Typically, the destruction of the American World Trade Center at apocalyptic proportions by these forces of terror etched on the sands of history on September $11^{\text {th }}$, 2001 (the historic $9 / 11$, as so called) typifies the instances of oppositions, grievances and counter-hegemonic activities against unequal social exchange relations in the global landscape.

Although, such terrorist actions of the subaltern individuals may or may not produce progressive social change, the bit about the interpenetrations of 'social exchange' and 'social change' with regard to the human condition, is that unequal power relations in any existing social exchange process between parties is capable of reproducing change -whether progressive, retrogressive or admixture of the two; whereas there is a semblance of order in any social exchange process that exhibits 'equal power' relations -this, however, usually not as praxis, but utopian. This is because, due to the hedonistic and selfish nature of man, there are always tendencies (covert or overt) of one party trying to subjugate the other, and hence breaching the grand norm of reciprocity that governs social exchange process where the aggrieved party reacts with resistance that ushers in social revolutions or change! Therefore, with the forgoing thought processes, the inter-linkages between the twin concepts of 'Social exchange and Social change', through constructive extrapolations and reconstructions, have fully been demonstrated.

\section{Summary}

From the onset, recall it was said that the raison d'etre of this endeavor is to examine the twin concepts of 'social exchange' and 'social change' in the works of Homans with the view of appropriating their implications as regards the amelioration of the human condition. You were also informed that the epicenter of Homans' social exchange theoretic perception is the grand 'norm of reciprocity' which preaches egalitarianism between the parties involved. As we saw in the forgoing discourse, Peter Blau's variant frame of reference to exchange process critically helped in examining social exchange relations in praxis situations. Hence, extrapolations and reconstructions were made with the help of the mediating notions of 'social contract' and 'legitimation-crisis' to examine the interpenetrations of the doctrinal ethos of social exchange and social change in praxis situations of 
the matrix of the state and the citizenry, and the global relations among nations in the world economic order, with regard to revealing its immanent contradictions and/or antinomies towards the amelioration of the human condition.

\section{Findings}

From our findings therefore, it was discovered that the tendencies of breaching the norm of reciprocity embedded in social exchange process are higher than the tendencies to maintain the norm -as regards what goes on with the political class and the ruled, as well at the global levels among nations. Again, it was equally discovered that, at the breach of the norm of reciprocity, there are higher risks of losses than the gains: its negative implications and immanent contradictions are evident at the individual level, and complex levels, like the state and the citizenry unequal structural relations; and the unequal structural economic relations among nations. Additionally, the findings also reveal that societal progress or positive social change can also emerge via resistance to an 'apopular' status quo.

\section{Conclusion and Recommendations}

Therefore, the paper concludes that, there is semblance of order when the norm of reciprocity is observed, while aggression with immanent crisis-tendencies where the norm is violated -- and this is evident at the various levels of social exchange relations: the individual relations or dyad social exchange (between two individuals), the state and the citizenry, and ultimately within global relations among nations tinged with inequity and power imbalance.

For a way forward then, the following recommendations are proffered: there should be total commitment of the state to its part of the bargain in the social contract with the citizenry with evidence of the provisions of human centered development facilities for the improvement of the human condition -since the lack of these prerequisites breed aggression and political instability which is anti-development. Additionally, where the state loses the sanctity of its legitimacy, revolutions by the civil society, in the exercise of their inalienable political rights, geared towards progressive social change to ameliorate the socioeconomic conditions should not be discouraged. Again, the advanced nations should recognize and respect the right of the less developed nations for a fair deal in the global economic relations. Ultimately, there is the need to restrain, as much as possible, selfish interest in exchange relationship by the social actors or parties involved. Social justice along the lines of quid pro quo should be respected by social actors, and should remain a sacred-line not to be crossed or undermined by any party involved in the exchange relations.

\section{References}

Abend, G. (2008). Sociological Theory. Wiley Online Library. Volume 26, pp.173-199. www.onlinelibrary.wiley.com/doi/full/10.ml/pp.173-199.

Appadorai, A. (2003). The Substance of Politics. New Delhi: Oxford University Press.

Chang, H. (2002). "Kicking Away the Ladder: How the Intellectual Histories of Capitalism has been Re-written to justify Neoliberal Capitalism. Post-Historic Economics Review. Issue 15 (3).

Cook, K.S, Cheshire, L., Rice, E.R.W \& Nakagawa, S. (2013). Social Exchange theory. In, J. DeLameter \& H. Ward (Eds.), Handbook of Sociology and Social Research. Handbook of Social Psychology (p.61-88). Springer Science + Business Media. www.//doi.org/10.1007/978-94-0o7-0772-o_3

Cristobel, K. (2018). Andre Gunder Frank: From the 'Development of Underdevelopment' to the World system'. Development and Change. 36 (6): 1177-1183

Daily Independent (July 31, 2010). Nigeria: \$12.4 Billion Oil Windfall -Presidency Stuck over Probe of IBB. www.dailyindependent.ng/nigeria-\$12.4-billion-oil-windfall-president-stuck-over-probe-of-ibb/

Fararo, T. (2015). 'Homans George (1910-1989). In, Blackwell Encyclopedia of Sociology (pp 2144-2146) $2^{\text {nd }}($ ed.) (Ritzer George) (ed.). New Jersey: John Wiley \& Sons 
Gordon, A. (2003). A Modern History of Japan: From Tokugawa Times to the Present. New York: Oxford University Press.

Hunt, M. (2016). The Transformed. From 1945 to Present. New York City: Oxford press

Leicht, K.T. and Harper, C.L (2018). Exploring Social Change: America and the World (7 ${ }^{\text {th }}$ Ed.). U.S.A: Taylor and Francis.

Levin, N. (2021, March 10). Treatise on Human Nature (David Hume). U.C Davis Library. California StateUniversity .www.human.libretexts.org/ego/p

Mossi, F., Jayme, J.R., Frederico, G. and Oreiro, J.L (2015). 'The Structuralist tradition In Economics: Methodological and Macroeconomics Aspects'. Revista de Economica Politica Journal. Vol. 35. No 2 (April/June Edition).

Muldoon, J., Liguori, E.W., Benedickson, J., \& Bauman, A. (2018). 'Revisiting perspectives on George Homans: Correcting Misconceptions. Journal of Management History, 24 (1), 57-75.

NBS (2003). Poverty Profile for Nigeria - 2003 edited report for Nigeria. National Bureau of Statistics. www.nigerianstat.gov.ng

NBS (2020). Poverty and Inequality in Nigeria 2019: Executive Summary. www.nigerianstat.gov.ng

Ninalowo, A. (2000). Bureaucracy and Social Change: Studies in Bureaucracy and Underdevelopment. Lagos: Prime

Ninalowo, A. (2004). Essays on the State and Civil Society. Lagos: First Academy Publishers. p.129.

Ninalowo, A. (2004). Essays on the State and Civil Society. Lagos: First Academy Publishers. p.7.

Ninalowo, A. (2004). Essays on the State and Civil Society. Lagos: First Academy Publishers. pp.37; 98.

Page, J. (2016). The East Asian Miracle and Development (Stiglitz): A Twenty Year Retrospective. In: Kato, H., Page, J., Shimomura, Y. (eds.). Japan's Development Assistance. London: Palmgrave Macmillian

Phillip, S. (2021). Jeremy Bentham and the Origins of Legal Positivism. Cambridge: University Press

Redmond, M.V (2015). Social Exchange Theory (Homans). English Technical Report and Whitepapers. 5. www.lib.iowastate.edu./engl_reports/5

Ritzer, G. (2007) (ed.). The Blackwell Encyclopedia of Sociology. Malden, MA: Blackwell Pub

Scott, R. and Craig, C. (2004). 'Biographical Memoirs: Volume 85, Peter Michael Blau'. National Academy of Science: The National Academies Press

Seidman, S. (2016). Contested Knowledge: Social Theory today. New Jersey: John Wiley \& Sons.

UNDP (1991). Human Development Report. New York: Oxford University Press

Vanguard (February 17th, 2018). 'Snake allegedly swallows N36 million from JAMB office vault, Nigerians react'. www.vanguardngr.com/2018/o2-snake-allegedly-swallows-n36m-from-jamb-vault-nigeriansreact/.

Vanguard (February 21, 2018). 'Shocker! Monkeys swallow N70 million belonging to Northern Senators Forum. www.vanguardngr.com/2018/o2-monkeys-swallow.n7om/.

World Bank (2001). Rethinking the East Asian Miracle. In, Stiglitz, J.E, and Yusuf, S. (eds.).Washington, D.C: World Bank and Oxford University Press. www.openknowledge.worldbank.org/10896/13969

World Bank (2020). Advancing Social Protection in a Dynamic Nigeria. The World Bank Group.

www.worldbank.org 